\title{
CAPRICE NO. 24 KARYA PAGANINI PADA SOLO GITAR ARANSEMEN JOHN WILLIAMS (ANALISIS BENTUK MUSIK)
}

\author{
Agus Suwahyono \\ Program Studi Seni Musik, Fakultas Bahasa dan Seni, Universitas Negeri Surabaya \\ Email: agussuwahyono@unesa.ac.id
}

\begin{abstract}
Caprice no. 24 is one of 24 caprice created by Paganini, Caprice (capricio) is a short and lively light music, especially for the instrument of klaviatur, known in the 17th century. Capricio is arranged in fuga form. In addition there is a mention of Capricio as a composition that does not comply with certain rules. Caprice no. Paganini's guitar solo arrangement by John Williams included one of the compositions with variations, from a theme developed with a variety of variations of rhythm, harmony, melody, etc. Themes in Caprice no. 24 consists of 12 bars, then developed from 1 to 13 variations (Finale), which totals 158 bar. Analysis of variations of Paganini's work "Caprice no. 24 "is as follows: Variations to: (1) Variations with constant harmony, (2) Variations of Melody, (3) Variations of harmony, (4) Variations of Melody, (5) Variations of Melody, (6) Harmony Variations, (7) (9) Variations of Melody, (10) Variations of melody and rhythm, (11) Free variation, (12) Variation of Character, (13) Finale; Free variation.
\end{abstract}

Key Words: Caprice, Variation form

\begin{abstract}
Abstrak: Caprice no. 24 merupakan salah satu dari 24 caprice yang diciptakan oleh Paganini, Caprice (capricio) adalah musik ringan yang pendek dan lincah, khusus bagi alat musik klaviatur, dikenal dalam abad ke-17. Capricio disusun dalam bentuk fuga. Selain itu ada yang menyebut Capricio sebagai sebuah komposisi yang tidak menuruti peraturan tertentu. Caprice no. 24 karya Paganini aransemen solo gitar oleh John Williams termasuk salah satu karya komposisi dengan bentuk variasi, dari tema yang kemudian dikembangkan dengan berbagai macam variasi baik irama, harmoni, melodi, dan seterusnya. Tema dalam Caprice no. 24 terdiri dari 12 birama, kemudian dikembangkan mulai dari variasi 1 sampai dengan variasi 13 (Finale), yang secara keseluruhan mencapai 158 birama. Analisis bentuk variasi karya Paganini "Caprice no. 24" adalah sebagai berikut: Variasi ke: (1) Variasi dengan harmoni tetap, (2) Variasi Melodi, (3) Variasi harmoni, (4) Variasi Melodi, (5) Variasi Melodi, (6) Variasi Harmoni, (7) Variasi Harmoni dan Irama, (8) Variasi bebas, (9) Variasi Melodi, (10) Variasi melodi dan ritme, (11) Variasi bebas, (12) Variasi Karakter, (13) Finale; Variasi bebas.
\end{abstract}

Kata kunci: Caprice, Bentuk variasi

\section{PENDAHULUAN}

Caprice (capricio) adalah musik ringan yang pendek dan lincah, khusus bagi alat musik klaviatur, dikenal dalam abad ke17. Biasanya capricio disusun dalam bentuk fuga (Banoe, 2003). Dalam pengertian lain capricio adalah sebuah komposisi yang tidak menuruti peraturan tertentu (Syafiq, 2003). Dari beberapa pengertian diatas ternyata capricio mengandung dua arti yang pertama biasanya disusun dalam bentuk fuga yang ke dua adalah sebuah komposisi yang tidak menuruti peraturan.

Terlepas dari kedua pengertian tersebut diatas caprice no.24 karya Paganini nantinya akan kami analisis berdasarkan buku "struture \& Style : The Study and Analysis of Musical Form". Adapun analisisnya adalah terfokus pada analisis bentuk musik caprice no. 24 karya Paganini aransemen solo gitar oleh John Williams.

Adapun nama lengkap Paganini adalah Niccolo Paganini (1782-1840), pemain biola, lahir di Genoa pada tanggal 27 Oktober 1782. Orang tuanya sangat miskin, tetapi bakatnya luar biasa menjadikan Paganini mendapat pendidikan musik yang baik. Dari tahun 1798 hingga 1804, ia hidup dalam keprihatinan dan melarat. Ketika sebagai pemain biola pada tahun 1805 , reputasi Paganini sebagai pemain musik tersebar luas.

Penampilan pertamanya di luar Italia, yaitu di Wina, pada tahu 1828, menghasilkan antusiasme tinggi yang nyaris menjadi histeria. Ia bermain dengan sukses yang membuat penonton tergila-gila di Jerman, Prancis dan Belanda. Karena kurus kering dan penampilanya yang agak menyeramkan, ia 
sering dituduh sebagai anggota perkumpulan pemuja setan. Pada tahun 1834, kesehatan Paganini memburuk secara drastis dan dalam keadaan sakit tuberkolosis, ia pindah ke Nice pada tahun 1839. Ia meninggal di kota tersebut pada tanggal 27 Mei 1840.

Paganini merupakan master biola yang sempurna. Ia juga seorang penulis lagu yang sangat orisinal, khususnya pada pemain biola. Selain itu ia juga menguasai permainan gitar dan viola (biola alto). Sebagai pemain biola, kemasyhuran permainannya memang tercatat dalam sejarah. Dengan penguasaan terhadap nada-nada harmonik, ia mampu menjangkau nada-nada yang jauh lebih luas. Selain terampil bermain dalam satu dawai, kelebihan yang lain adalah kepandaianya dalam meramu teknik pizzicato dan arco secara cepat. Sebagai seorang komponis, ia meninggalkan sejumlah komposisi. Diantaranya 24 buah capricio (untuk biola tunggal), 5 konserto biola, dan musik kamar untuk gitar dan string (Syafiq, 2003).

Caprice no. 24 karya N. Paganini merupakan musik instrumental format solo gitar yang diaransemen oleh John Williams yang merupakan salah satu gitaris terbaik di dunia, dilahirkan di Melbourne, Australia, 24 April 1929. Adapun nama lengkapnya adalah John Christopher Williams. Ia disebut-sebut sebagai maestro gitar yang setera dengan Andres Segovia dari Spanyol. Sejak tampil di Amerika pada tahun 1960-an lalu, Wiliiams dikontrak secara eksklusif oleh CBS Masterworks yang sekarang bernama Sony Classical, selanjutnya bagaimanakah bentuk musik dari salah satu capricio (caprice no 24) karya Paganini yang diaransemen solo gitar oleh John Williams?.

\section{PEMBAHASAN}

Bentuk Musik

Bentuk musik (form), dalam buku "Ilmu Bentuk Musik" (Edmun Prier,1996) diterangkan bahwa; Bentuk Musik = Suatu gagasan/ ide yang nampak dalam pengolahan/ susunan semua unsur musik dalam sebuah komposisi (melodi, irama, harmoni dan dinamika). Ide ini mempersatukan nada-nada musik serta terutama bagian-bagian komposisi yang dibunyikan satu per satu sebagai kerangka. Dalam buku tersebut juga diuraikan berbagai macam bentuk- bentuk musik, al; (1) Bentuk lagu/ Bentuk bait (Liedform); (2)
Bentuk Variasi; (3) Bentuk Rondo; (4) Bentuk Suita; (5) Bentuk Sonata, dll.

Salah satu bentuk musik yang menarik adalah bentuk variasi yang ada pada karya Paganini yaitu: Caprice No. 24. Hal tersebut seperti yang telah diungkapkan oleh Stein (1979), "The Theme on which a set of variations is based may be original (Paganini, Caprice No. 24)".

Menurut Prier (1996): Bervariasi berarti mengulang sebuah lagu induk yang biasanya disebut 'tema' dengan perubahan (disebut variasi-variasi) sambil mempertahankan unsur tertentu dan menambah/menggantikan unsur yang lain. Maka variasi termasuk teknik komposisi yang terpenting, dan ternyata dipakai dalam musik primitif sampai dalam musik klasik dan modern, di barat dan timur. Di Indonesia banyak dipakai dalam iringan tarian dan dalam lagu sahut-menyahut seperti pantun $\mathrm{dsb}$. Jenis variasi berpangkal dari tiga unsur pokok dari musik: (1) melodi, (2) Irama, (3) harmoni/aransemen.

\section{Variasi melodi}

Nada-nada pokok melodi tetap dipakai sebagai nada kerangka, namun dihias ('teknik bunga", teknik figural', "kolorierung"). Nilai nada-nada pokok dijadikan nada lebih kecil (diminuation).

\section{Variasi irama}

Panjang - pendeknya nada dirubah atau birama (hitunganya) dirubah, ataupun tempo dirubah.

\section{Variasi harmoni}

Lagunya tetap, namun akor pengiring divariasi, misalnya dengan dibantu akor minor, dengan modulasi-modulasi; atau seluruh lagu (mayor) diminorkan

\section{Variasi polifon}

Dengan imitasi motif, atau dengan menirukan lagu pokok dalam suara-suara selain sopran terbentuklah kontrapungkontrapung.

\section{Variasi karakter}

Dalam hal ini melodi, irama dan harmoni dapat mengalami perubahan cukup banyak demi untuk mengungkapkan suatu ciri/sikap/pola yang khas.

\section{Variasi bebas}

Disini sering seluruh tema divariasikan tetapi hanya sbuah motif dari lagu asli (motif melodi atau motif irama) 
. Karena agak bebas juga, maka sering agak sukar untuk menemukan relasinya pada tema/lagu asli. Teknik variasi bebas umumnya terdapat menjelang akhir deretan variasi (Edmund Prier, 1996).

\section{Bentuk Musik Caprice No. 24 Karya Paganini}

Caprice no. 24 karya Niccolo Paganini merupakan salah satu jenis musik instrumental dengan bentuk variasi artinya lagu induk atau biasa disebut dengan 'tema' yang kemudian diulang lagi dengan variasi 1, variasi 2 , variasi 3 , dan seterusnya.

Musik instrumental adalah permainan musik tanpa vokal (Banoe, 2003). Umumnya sampai masa Barok musik instrumental tidak mandiri tetapi berperan untuk mengiringi tari dan nyanyi, untuk menghibur. Maka cukup diimprovisasi saja. Musik instrumental dengan tujuan pada dirinya sendiri baru mulai berkembang pada abad 16 dengan diterapkan bentuk dan teknik komposisi vokal pada instrumen, dengan beberapa penerapan kecil. Dengan demikian lahirlah bentuk Ricercare, Toccata, Canzona, Sonata dsb (Edmund Prier,19991).

Caprice no. 24 karya Paganini termasuk salah satu karya komposisi dengan bentuk variasi, dari tema yang kemudian dikembangkan dengan berbagai macam variasi baik irama, harmoni, melodi, dan lainlain.

Tema dalam Caprice no. 24 terdiri dari 12 birama, kemudian dikembangkan mulai dari variasi 1 sampai variasi 13 (Finale), yang secara keseluruhan mencapai 158 birama.

Analisis bentuk variasi karya Paganini "Caprice no. 24" adalah sebagai berikut:

Tema

Caprice no. 24 diawali dengan sebuah tema sepanjang duabelas birama dan di ulang dua kali. Pada bagian tema menggunakan tanda sukat duaperempat (2/4), nada yang dimainkan adalah nada-nada tunggal dengan di dominasi oleh nilai nada seperdelapan (1/8) dan nada-nada seperenambelas (1/16). Berikut potongan dari tema Caprice no, 24. Karya N. Paganini:
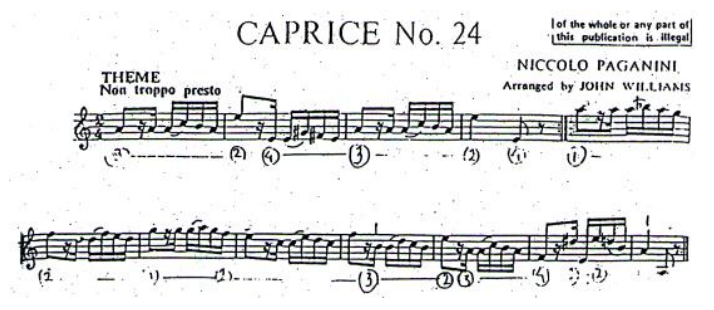

Variasi I : Variasi dengan harmoni tetap

Melodi kini sama sekali lenyap: nadanada pada tema diganti dengan arpeggio melalui 2 oktaf; irama pun mengalami perubahan dengan adanya nada-nada triol perdelapan. Namun harmoni serta bentuk dipertahankan.

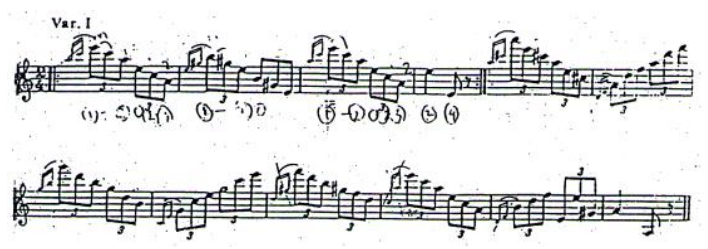

Variasi II : Variasi Melodi

Masing-masing nada dari lagu pokok kini diberi tambahan nada bawah yang berjarak setengah nada sehingga iramanya agak rapat, khususnya pada nada-nada bagian depan yang nilainya seperdelapan akhirnya menjadi seper-enambelasan hingga timbul kesan agak ramai. (sesuai dengan batas waktu yang sudah ditentukan)

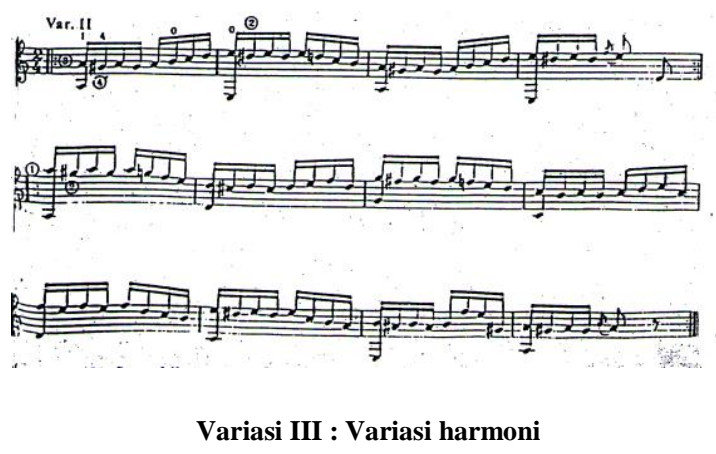

Melodi pada bagian ini dibuat agak renggang, dengan mengambil dari salah satu nada akor yaitu jarak terst dari melodi pokoknya, kemudian nada didobel dengan mengambil jarak oktafnya.

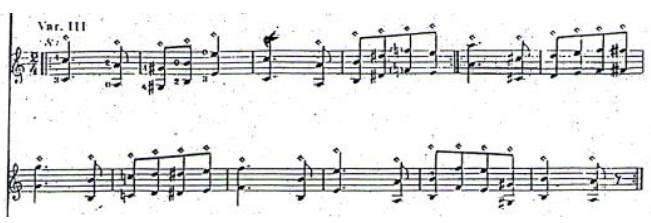


Variasi IV : Variasi Melodi

Nada-nada pokok melodi pada bagian ini masih nampak namun dihias, sehingga nada-nada secara keseluruhan menjadi seperenambelas, irama terkesan lebih padat.

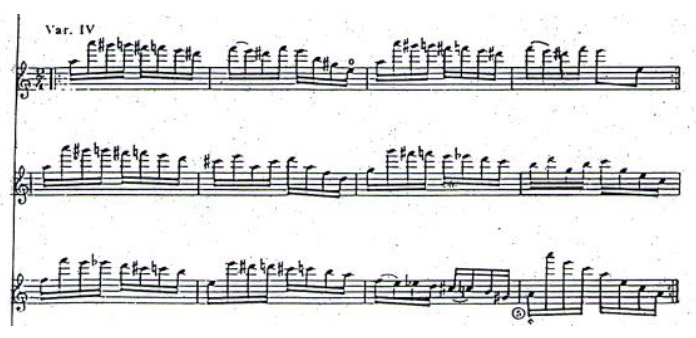

Variasi V : Variasi Melodi

Nada-nada pokok diambil satu nada kemudian dikembangkan dengan interval melompat keatas dan kebawah pada nada-nada lainya di luar akor.

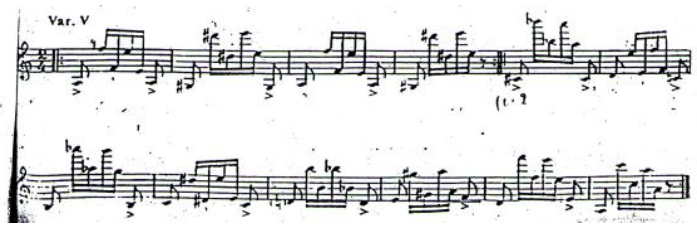

Variasi VI : Variasi Harmoni

Pada bagian ini melodi pokok tidak dikenal kembali, namun menggunakan melodi yang masih dalam satu wilayah akor dengan pendobelan interval terts sehingga masih tetap harmonis.

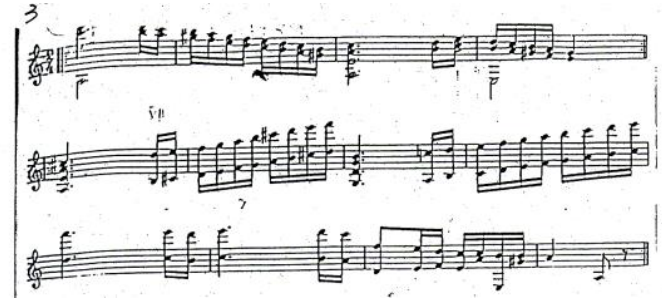

Variasi VII : Variasi Harmoni dan Irama

Nada-nada melodi pokok tidak muncul, tetapi yang muncul adalah nada yang berjarak kwint di atasnya dari melodi pokok, kemudian dikembangkan dengan hiasan naik setengah dan turun. Selain itu terdapat perubahan irama yaitu triol kecil dan seperempatan pada seluruh birama.

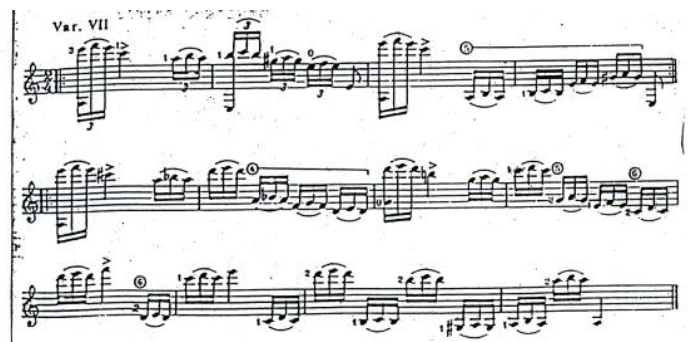

Variasi VIII : Variasi bebas

Yang paling menonjol di sini adalah perubahan hitungan dari 2/4 menjadi 4/4. Variasi melodi menggunakan nada-nada yang masih dalam satu anggota akor dengan dibunyikan satu persatu (arpeggio) dari satu hitungan menjadi enam nada.

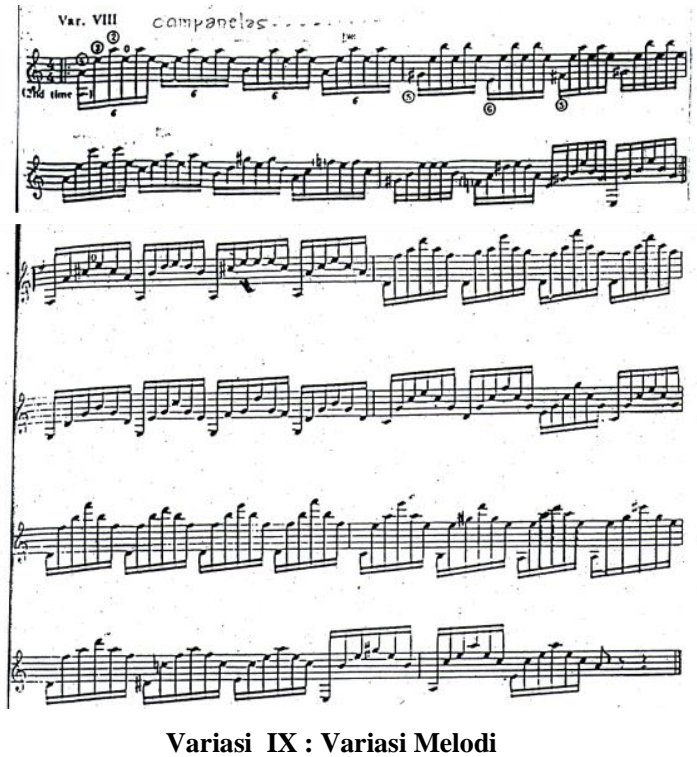

Di bagian ini melodi pokok awal diambil dari salah satu anggota akord baik yang berjarak terts diatasnya maupun jarak kwint diatasnya membentuk petikan arpeggio dari atas kebawah.

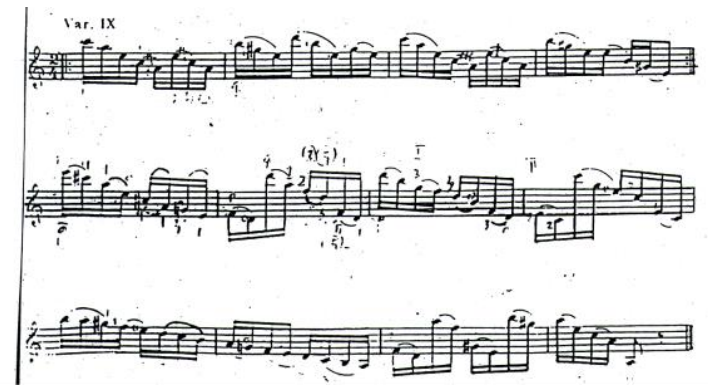

Variasi X : Variasi melodi dan ritme 
Di sini melodi divariasi dengan hiasan dan sebagian menggunakan nada dari akor yang dibunyikan satu per-satu (arpeggio), selain itu ada perubahan ritme sehingga permainan agak kendor dari bagian sebelumnya.

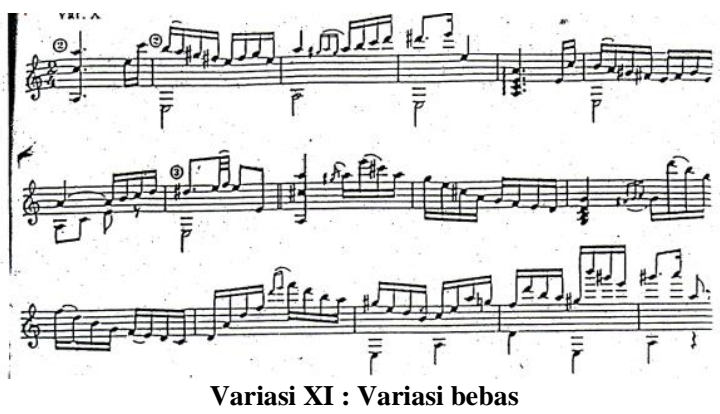

Tanda sukat masih duaperempat (2/4) meskipun bebas, melodi sebagian dipadatkan lagi dari variasi sebelumnya, kali ini nada-nada dari anggota akor dibunyikan satu-satu dengan didobel (nada-nada dipetik ulang), sehingga terkesan ramai. Berikut potongan partitur variasi sebelas dapat dilihat di halaman selanjutnya:

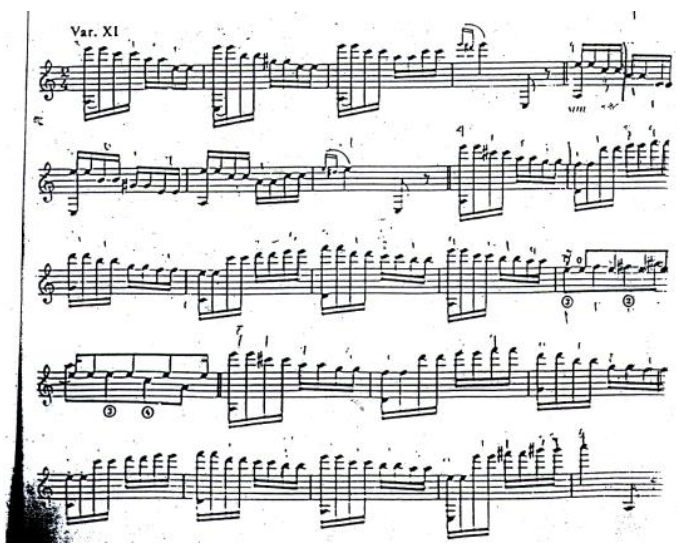

Variasi XII : Variasi Karakter

Di bagian ini motif melodi pokok tidak kelihatan lagi artinya lenyaplah dia dalam teknik struming dan petikan arpeggio dengan nilai nada yang padat yaitu $1 / 32$ dan $1 / 16$, sehingga musik terkesan ramai dan padat. Berikut potongan partitur variasi sebelas dapat dilihat di halaman selanjutnya:

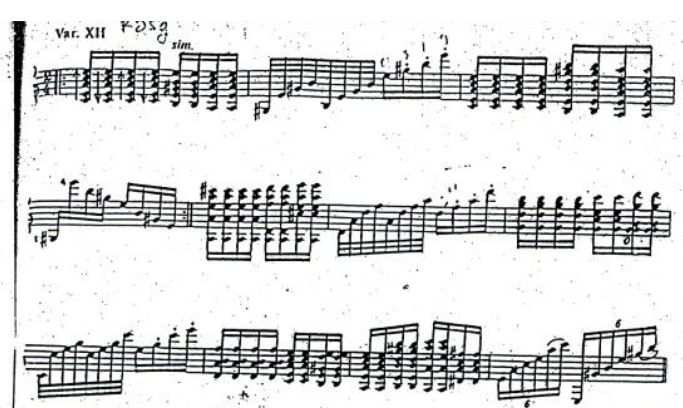

Variasi XIII (Finale) : Variasi bebas

Nada-nada dari anggota akord imunculkan satu persatu dengan rapat artinya atu hitungan terdapat enam nada yang dibunyikan, selain itu ada 2 birama membunyikan akord dengan nilai nada 1/16. Ciri dari bagian ini adalah lebih bebas dan biasanya lebih panjang pula.

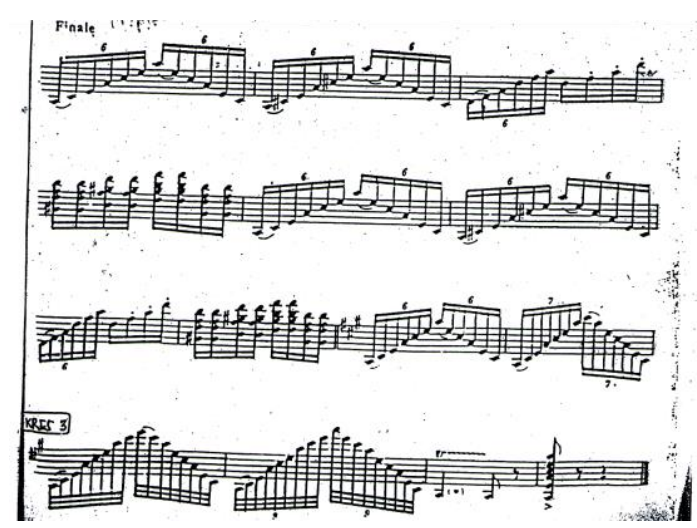

\section{PENUTUP}

Caprice no 24 merupakan salah satu dari 24 caprice yang diciptakan oleh Paganini, Caprice (capricio) adalah musik ringan yang pendek dan lincah, khusus bagi alat musik klaviatur, dikenal dalam abad ke17. Biasanya capricio disusun dalam bentuk fuga. Namun ada yang menyebut sebagai sebuah komposisi yang tidak menuruti peraturan tertentu.

Paganini merupakan master biola yang sempurna. Ia juga seorang penulis lagu yang sangat orisinal, khususnya pada pemain biola. Selain itu ia juga menguasai permainan gitar dan viola (biola alto). Sebagai pemain biola, kemasyhuran permainannya memang tercatat dalam sejarah.

Caprice no. 24 karya Paganini yang di aransemen format solo gitar oleh John Williams termasuk salah satu karya komposisi 
dengan bentuk variasi, dari tema yang kemudian dikembangkan dengan berbagai macam variasi baik irama, harmoni, melodi, dll.

Tema dalam Caprice no. 24 terdiri dari 12 birama, kemudian dikembangkan mulai dari variasi 1 sampai variasi 13 (Finale), yang secara keseluruhan mencapai 158 birama.

Analisis bentuk variasi karya Paganini "Caprice no. 24" adalah sebagai berikut: Variasi 1: Variasi dengan harmoni tetap; Variasi 2: Variasi Melodi; Variasi 3: Variasi harmoni; Variasi 4: Variasi Melodi; Variasi 5: Variasi Melodi; Variasi 6: Variasi Harmoni; Variasi 7: Variasi Harmoni dan Irama; Variasi 8: Variasi bebas; Variasi 9: Variasi Melodi; Variasi 10: Variasi melodi dan ritme; Variasi 11: Variasi bebas; Variasi 12: Variasi Karakter; Variasi 13 (Finale): Variasi bebas.

\section{DAFTAR PUSTAKA}

Banoe, Pono. (2003). Kamus Musik. Yogyakarta: Kanisius

Prier, Karl-Edmund sj. (1996). Ilmu Bentuk Musik. Yogyakarta: Pusat Musik Liturgi.

Prier, Karl-Edmund sj. (1991) Sejarah Musik Jilid 1. Yogyakarta: Pusat Musik Liturgi.

Stein, leon. (1979). Structure \& Style: The Study and Analysis of Musical Form. Expanded ed. New Jersey: SummyBirchard Music.

Syafiq, M. (2003). Ensiklopedia Musik Klasik. Yogyakarta: Adicita Karya Nusa. 